\title{
KONTRIBUSI KOMPENSASI DAN MOTIVASI KERJA TERHADAP KEPUASAN KERJA PEGAWAI DI DINAS PENDIDIKAN DAN KEBUDAYAAN KABUPATEN AGAM
}

\section{NIKA SAPUTRA, RIZKI AFRI MULIA}

\begin{abstract}
This study aims to provide evidence that: (1) To see the contribution of compensation to the job satisfaction of Agam Regency Education and Culture Department employees. (2) To see the contribution of work motivation to the job satisfaction of Agam Regency Education and Culture Office employees. (3) To see the contribution of compensation and work motivation together to the job satisfaction of Agam Regency Education and Culture Department employees. Data collection is done by survey method with questionnaire. the auditor Data analysis techniques used in this study are descriptive and quantitative analysis. The data collected is primary and secondary data that can be classified as independent variables and dependent variables. Work Compensation and Motivation (contribution variables), and Employee Job Satisfaction in the Agam Regency Education and Culture Office (contributed variable). Hypothesis testing in this study uses multiple linear regression test. Based on the results of the study note that: (1) There is a positive and significant contribution between compensation for Employee Job Satisfaction in the Agam District Office of Education and Culture. (2) There is a positive and significant contribution between work motivation on Employee Job Satisfaction in Agam Regency's Office of Education and Culture. (3) There is a positive contribution between compensation and work motivation together to Employee Job Satisfaction in Agam Regency's Office of Education and Culture.
\end{abstract}

Keywords: Compensation, Work Motivation, Job Satisfaction.

Abstrak: Penelitian ini bertujuan untuk memberikan bukti bahwa : (1) Untuk melihat kontribusi kompensasi terhadap kepuasan kerja pegawai Dinas Pendidikan dan Kebudayaan Kabupaten Agam. (2) Untuk melihat kontribusi motivasi kerja terhadap kepuasan kerja pegawai Dinas Pendidikan dan Kebudayaan Kabupaten Agam. (3) Untuk melihat kontribusi kompensasi dan motivasi kerja secara bersama-sama terhadap kepuasan kerja pegawai Dinas Pendidikan dan Kebudayaan Kabupaten Agam. Pengumpulan data dilakukan dengan metode survei dengan kuesioner. pada auditor Teknik analisa data yang digunakan dalam penelitian ini adalah analisis deskriptif dan kuantitatif. Data yang dikumpulkan merupakan data primer dan sekunder yang dapat digolongkan sebagai variabel bebas dan variabel terikat. Kompesasi dan Motivasi Kerja (variabel kontribusi), dan Kepuasan Kerja Pegawai di Dinas Pendidikan dan Kebudayaan Kabupaten Agam(variabel terkontribusi). Pengujian hipotesis dalam penelitian ini menggunakan uji regresi linier berganda. Berdasarkan hasil penelitian diketahui bahwa : (1) Terdapat kontribusi positif dan signifikan antara kompensasi terhadapKepuasan Kerja Pegawai di Dinas Pendidikan dan Kebudayaan Kabupaten Agam. (2) Terdapat kontribusi positif dan signifikan antara motivasi kerja terhadap Kepuasan Kerja Pegawai di Dinas Pendidikan dan Kebudayaan Kabupaten Agam. (3) Terdapat kontribusi positif antara kompensasi dan motivasi kerja secara bersama-sama terhadap Kepuasan Kerja Pegawai di Dinas Pendidikan dan Kebudayaan Kabupaten Agam. 
Kata Kunci: Kompensasi, Motivasi Kerja, Kepuasan Kerja.

\section{A. Pendahuluan}

Sumber Daya Manusia (SDM) merupakan elemen terpenting dalam instansi pemerintah yang bertugas untuk menggerakkan dan mewujudkan visi dan misi organisasi pemerintah. Roda globalisasi yang terus bergerak cepat menuntut pemerintah untuk memanajemen SDM dengan lebih baik agar SDM mampu menghadapi perubahan-perubahan baik dari segi teknologi dan budaya. Tercapainya tingkat kinerja SDM yang bagus tidak lepas dari tingginya tingkat kepuasan kerja pegawai atas pekerjaannya didalam sebuah organisasi. Pushpakumari (2008) dalam penelitiannya membuktikan bahwa kinerja seorang pegawai dipengaruhi oleh tingkat kepuasan kerja pegawai di organisasi tempat ia bekerja. Maka untuk mencapai kinerja pegawai yang bagus, organisasi perlu memperhatikan kepuasan kerja pegawai secara terus menerus. Kreitner dan Kinicki (2005) mendefiniskan kepuasan kerja sebagai sebuah sikap dan respon emosional seseorang atas berbagai sisi pekerjaannya. Locke (1968) juga mendefinisikannya sebagai sebuah respon emosional yang berasal dari apa yang telah mereka berikan kepada organisasi dan apa yang mereka harapkan dari organisasi tersebut.

Kepuasan kerja mencerminkan perasaan seseorang kepada pekerjaannya. Hal ini terlihat dalam sikap positif pegawai terhadap pekerjaan dan segala sesuatu yang dihadapi dilingkungan kerjanya. Kepuasan kerja secara umum menyangkut sikap seseorang mengenai pekerjaannya. Kepuasan kerja merupakan salah satu aspek penting yang harus dimiliki seorang pegawai agar mampu bekerja dengan baik sesuai dengan yang diharapkan. Kepuasan kerja adalah suatu kondisi mental seseorang pegawai mengenai suka atau tidak suka terhadap pekerjaannya yang dipengaruhi oleh persepsi dan harapannya terhadap pekerjannya dan dengan demikian akan mempengaruhi perilaku kerjanya. Sistem Kompensasi diharapkan dapat meningkatkan semangat kerja semaksimal mungkin dalam batas-batas kemampuan/anggaran dana tersebut. Hal ini penting, sebab dengan anggaran dana dan kemampuan yang terbatas kita harus memilih satu cara yang paling tepat untuk meningkatkan semangat kerja. Kompensasi merupakan faktor yang dapat mempengaruhi kepuasan kerja bagi Pegawai dalam bekerja pada suatu Instansi pemerintahan. Salah satu bidang manajemen sumber daya yang penting bagi karyawan adalah kompensasi. Menurut T. Hani Handoko (2001 : 155) Kompensasi adalah segala sesuatu yang diterima para karyawan sebagai balas jasa untuk kerja mereka. Dengan adanya kompensasi maka karyawan merasakan adanya suatu ikatan dengan perusahaan. Selain kompensasi, perusahaan bias memberikan rasa aman, nyaman serta adanya fasilitas yang cukup serta memadai bagi karyawan.

Instansi Pemerintahan dalam hal ini Dinas Pendidikan dan Kebudayaan Kabupaten Agam menggunakan berbagai imbalan untuk menarik dan mempertahankan orang-orang dan memotivasi mereka agar mencapai tujuan pribadi dan instansi tersebut. Cara dan waktu mendistribusikan pemberian imbalan tersebut adalah masalah penting sehingga pimpinan harus membahasnya dengan serius. Pimpinan memberikan imbalan seperti upah, alih tugas, promosi, pujian dan pengakuan. Pimpinan dapat juga membantu menciptakan iklim yang menghasilkan pekerjaan yang lebih banyak tantangannya dan memuaskan. Karena imbalan ini dianggap penting oleh pegawai, imbalan tersebut mempunyai dampak yang penting atas perilaku dan prestasi. Kebijakan Kompensasi selain memberikan imbalan pada pegawai atas pekerjaan yang dilakukan pegawai juga merupakan salah satu cara yang efektif untuk E-ISSN: 2657-0300 Lembaga Penelitian dan Penerbitan Hasil Penelitian Ensiklopedia $\quad 21$ 
mempertahankan pegawai potensial, oleh karena itu pemberian kompensasi perlu mendapat perhatian khusus dan dilaksanakan atas dasar kepentingan instansi maupun kebutuhan pegawai, sehingga menghasilkan manfaat yang maksimal. Salah satu fungsi manajemen sumber daya manusia yang penting bagi pegawai adalah kompensasi. Dengan adanya kompensasi maka pegawai merasakan adanya suatu ikatan dengan Instansi. Selain kompensasi,instansi biasa memberikan rasa aman, nyaman serta adanya fasilitas yang cukup serta memadai bagi pegawai. Menurut Handoko $(2001,155)$ kompensasi adalah segala sesuatu yang diterima para pegawai sebagai balas jasa untuk kerja mereka,dengan adanya pemberian kompensasi kepada para pegawai dapat memberikan rasa kepuasan kerja bagi pegawai.

Dinas Pendidikan dan Kebudayaan Kabupaten Agam yang merupakan salah satu organisasi/lembaga yang berperan dalam mengembangkan, meningkatkan kualitas dan mengkoordinasi unsur pendidikan dalam masyarakat di tingkat Provinsi. Di lembaga inilah aktifitas para pegawai diharapkan mampu berperan dalam mewujudkan suatu pola pendidikan serta mampu mengatasi segala permasalahan yang berhubungan dengan kualitas pendidikan dilingkup daerah. Berdasarkan observasi awal yang peneliti lakukan di Dinas Pendidikan Dan Kebudayaan Kabupaten Agam, ternyata masih cukup banyak terjadi kesenjangan yang kurang sesuai dengan idealisme, masih ada beberapa kelemahan yang masih ditunjukkan oleh karyawan/pegawai dimana mereka kurang termotivasi dengan pekerjaannya. Ada yang tidak tepat waktu saat masuk kantor, menunda tugas kantor, kurang disiplin waktu dan tidak bisa memanfaatkan sarana kantor dengan baik. Hal inilah yang perlu mendapatkan perhatian dari pihak manajerial terutama pimpinan lembaga, agar dapat sedini mungkin mencegah dan berupaya meningkatkan kualitas manajemen sumber daya manusia yang ada pada lembaga tersebut.

Berdasarkan uraian latar belakang diatas, penulis mengidentifikasi beberapa masalah sebagai berikut: 1) Tingkat kehadiran pegawai Dinas Pendidikan dan Kebudayaan Kabupaten Agam yang mengalami fluktuasi. 2) Suasana kerja di Dinas Pendidikan dan Kebudayaan Kabupaten Agam yang kurang kondusif. 3) Kurangnya penghargaan yang diberikan oleh atasan kepada pegawai di Dinas Pendidikan dan Kebudayaan Kabupaten Agam. 4) Kurangnya komunikasi dan koordinasi kerja antar pegawai di Dinas Pendidikan dan Kebudayaan Kabupaten Agam. 5) Pegawai Dinas Pendidikan dan Kebudayaan Kabupaten Agam cenderung kurang serius dalam memberikan pelayanan dan tidak sigap dalam merespon keluhan masyarakat. 6) Pemberian motivasi yang tidak merata antara pegawai dijabatan yang sama. 7) Kurangnya ketekunan pegawai Dinas Pendidikan dan Kebudayaan Kabupaten Agam dalam bekerja. 8) Pegawai Dinas Pendidikan dan Kebudayaan Kabupaten Agam cenderung bekerja ketika berada dalam pengawasan atasan saja. Pembatasan masalah dilakukan untuk memberikan arahan pada masalah yangakan diteliti sehingga maksud dan tujuan tercapai, maka penelitian ini penulis membahas tentang Kontribusi Kompensasi dan Motivasi Kerja terhadap Kepuasan Kerja Pegawai Dinas Pendidikan dan Kebudayaan Kabupaten Agam.

\section{B. Metodologi Penelitian}

Penelitian ini terdiri dari tiga variabel yaitu variabel bebas dan variabel terikat. Variabel bebas dalam penelitian ini adalah Kompensasi (X1), dan Motivasi Kerja (X2), sedangkan variabel terikat Kepuasan Kerja Pegawai di Dinas Pendidikan Dan 
Kebudayaan Kabupaten Agam (Y). Pada Penelitian ini yang menjadi sampel penelitian untuk sebaran kuesioner adalah pegawai yang ada di Dinas Pendidikan Dan Kebudayaan Kabupaten Agam. Diketahui bahwa kepuasan kerja dilihat dari 9 indikator seperti indikator gaji dengan skor mean 4,76, indikator promosi dengan skor mean 4,21, indikator supervisi dengan skor mean 4,32, indikator tunjungan tambahan dengan skor mean 3,70, indikator penghargaan dengan skor mean 4,19, indikator prosedur dan peraturan kerja dengan skor mean 4,25, indikator rekan kerja dengan skor mean 4,24, indikator pekerjaan itu sendiri dengan skor mean 3,88, dan indikator komunikasi dengan skor mean 4,00. Secara umum bisa dikatakan kepuasan kerja pegawai sudah baik hal ini terlihat dari skor variabel mean 4,16 .

\section{Hasil dan Pembahasan}

\section{Kontribusi Kompensasi (X1) Terhadap Kepuasan Kerja Pegawai di Dinas Pendidikan Dan Kebudayaan Kabupaten Agam (Y)}

Salah satu faktor yang mengkontribusii kepuasan kerja seorang karyawan adalah kebijakan kompensasi yang berlaku di tempat kerjanya. Kompensasi dapat digunakan sebagai kunci untuk mengelola sumberdaya manusia secara efektif agar sesuai dengan kebutuhan bisnis dan kebutuhan karyawan (Schuler dan Jackson, 1996). Kompensasi juga dapat digunakan sebagai suatu cara untuk memotivasi, meningkatkan prestasi kerja, dan kepuasan kerja karyawan (Handoko, 1995). Oleh sebab itu penentuan kompensasi merupakan tugas yang kompleks, sulit, dan perlu mempertimbangkan berbagai faktor, karena menyangkut kepentingan organisasi maupun karyawan. Bagi organisasi kompensasi merupakan biaya yang relatif besar, sedangkan bagi karyawan kompensasi adalah sumber penghasilan untuk mempertahankan hidup mereka.

Menurut Schuler dan Jackson (1996) kepuasan karyawan terhadap kompensasi ditentukan oleh keadilan kompensasi, tingkat kompensasi, dan praktik administrasi kompensasi. Keadilan merupakan salah satu faktor penting yang perlu dipertimbangkan dalam menentukan tingkat kompensasi, baik keadilan internal maupun eksternal. Persepsi keadilan dikontribusi oleh: (1) rasio kompensasi dengan inputs seseorang seperti pendidikan, keahlian, keterampilan, pengalaman kerja, dan sebagainya; dan (2) perbandingan rasio tersebut dengan rasio-rasio yang diterima oleh orang lain. Oleh sebab itu dalam menentukan besar kecilnya kompensasi organisasi perlu mempertimbangkan adanya keadilan internal dan eksternal. Ketidakpuasan seringkali dikaitkan dengan tidak dipenuhinya rasa adil dan layak terhadap tingkat kompensasi yang mereka terima (Handoko, 1995).

Menurut teori Equity/keadilan karyawan akan merasa puas atau tidak puas tergantung pada persepsi mereka terhadap keadilan. Kepuasan atau ketidakpuasan karyawan merupakan hasil perbandingan antara input-outcomes dirinya dengan perbandingan input-outcomes karyawan lain. Apabila perbandingan tersebut dirasakan adil/equity maka karyawan tersebut cenderung puas, dan sebaliknya jika dirasakan tidak adil/inequity maka ada dua kemungkinan yaitu: (1) over compensation inequity; dan (2) under compensation inequity. Elemen-elemen penting dalam teori keadilan adalah input, outcomes, comparison person, dan equity atau inequity. Berdasarkan hasil riset tentang kepuasan kerja dengan teori equity, ternyata kepuasan kerja tercermin dari performance (As'ad, 2000; Mangkunegara, 2000).

Kepuasan terhadap tingkat kompensasi didasarkan pada perbandingan antara tingkat kompensasi dengan apa yang seharusnya mereka terima. Karyawan cenderung merasa puas apabila tingkat kompensasi yang seharusnya mereka terima sebanding dengan tingkat kompensasi aktual, dan tidak puas apabila tingkat kompensasi aktual E-ISSN: 2657-0300 Lembaga Penelitian dan Penerbitan Hasil Penelitian Ensiklopedia 23 
lebih kecil dari tingkat yang seharusnya. Kepuasan kompensasi berhubungan dengan perbedaan tingkat kompensasi pada tingkat pekerjaan atau jabatan yang berbeda-beda dalam suatu organisiasi (Schuler dan Jackson, 1996). Perbedaan kompensasi berkaitan dengan tugas dan tanggungjawab dari suatu pekerjaan, dan hirarki atau kedudukan seseorang dalam organisasi. Oleh sebab itu tidak mengherankan jika kompensasi manager lebih banyak daripada karyawan operasional. Pada umumnya karyawan akan menerima perbedaan tingkat kompensasi yang didasarkan pada tanggungjawab, produktivitas, kemampuan, pengetahuan, dan kegiatan-kegiatan managerial lainnya (Handoko, 1995).

Sementara itu faktor lain yang mengkontribusi kepuasan adalah praktik-praktik administrasi kompensasi. Menurut Mathis dan Jackson (2002) tujuan administrasi kompensasi adalah untuk memberikan gaji yang kompetitif dan adil. Hal-hal yang berkaitan dengan praktik-praktik administrasi kompensasi menurut Schuler dan Jackson, (1996):yaitu : (1) apabila tujuan organisasi untuk menarik orang-orang yang berkualitas tinggi agar bergabung ke dalam organisasi dan mempertahankan karyawan agar tetap puas dengan kompensasi yang mereka terima, maka sistem kompensasi paling tidak sama dengan kompensasi yang dibayarkan organisasi lain yang sejenis. Kompensasi sebaiknya menjamin adanya keadilan eksternal; (2) penetapan harga jabatan dapat meningkatkan kepuasan terhadap kompensasi yang mereka terima apabila dipandang mewujudkan filosofi kompensasi yang sebanding untuk jabatan dengan nilai setara. Oleh sebab itu evaluasi pekerjaan yang dilakukan dengan baik dapat membantu menentukan kesamaan kompensasi untuk pekerjaan yang dinilai sebanding; (3) sistem kompensasi berdasarkan kinerja sebaiknya disertai dengan metode pengukuran yang akurat dan terbuka, agar karyawan dapat melihat hubungan antara kompensasi dengan kinerja; (4) tingkat kompensasi sebaiknya selalu dievaluasi dan disesuaikan dengan perkembangan yang ada; dan (5) kepercayaan dan konsistensi kompensasi sebaiknya selalu dijaga. Karyawan seharusnya merasakan bahwa pimpinan organisasi betul-betul memperhatikan kepentingan mereka dan kepentingan organisasi. Kepercayaan dan konsistensi merupakan aspek penting yang mengkontribusi kepuasan terhadap kompensasi. Oleh sebab itu tanpa kepercayaan dan konsistensi, kepuasan terhadap kompensasi bisa menurun, dan kompensasi seringkali menjadi sasaran keluhan tanpa memandang persoalan yang sesungguhnya.

Kontribusi kompensasi terhadap kepuasan kerja merupakan bidang yang menarik untuk dikaji lebih lanjut. Faktor-faktor yang perlu diperhatikan dalam menentukan dan mendistibusikan kompensasi adalah (Gibson, Ivancevich dan Donnelly, 1996): (a) kompensasi sebaiknya dapat memuaskan kebutuhan dasar individu, misalnya makan, pakaian, dan tempat tinggal; (b) dipandang wajar/adil; dan (c) berorientasi pada individu.

Hasil penelitian ini menunjukkan bahwa kompensasi berkontribusi signifikan positif terhadap Kepuasan Kerja Pegawai di Dinas Pendidikan Dan Kebudayaan Kabupaten Agam. Dengan demikian, jika kompensasi yang diberikan kepada pegawai baik, dalam artian kompensasi tersebut sesuai dengan yang duharapkan pegawai, maka kepuasan kerja yang dihasilkan pada pegawai Dinas Pendidikan Dan Kebudayaan Kabupaten Agam lebih baik. Kompensasi kepada karyawan sangat memengaruhi motivasi kerja dan memberikan kepuasan kerja tersendiri bagi pegawai, apabila seorang karyawan mendapatkan kompensasi yang pantas atas apa yang sudah dikerjakan pada perusahaan makan tentunya seorang pegawai juga akan mendapatkan 
kepuasan kerja yang baik, hal ini juga dikuatkan oleh teori milik Hasibuan dalam Kadarisman (2012:86) bahwa tujuan pemberian kompensasi (balas jasa) adalah sebagai ikatan kerja sama, kepuasan kerja, pengadaan efektif, motivasi, stabilitas karyawan, disiplin serta pengaruh serikat buruh dan pemerintahan.

Hasil ini sesuai dengan penelitian yang dilakukan Anak Agung Ngurah Bagus Dhermawan, I Gde Adnyana Sudibya, dan I Wayan Mudiartha Utama (2012) dengan judul penelitian Pengaruh Motivasi, Lingkungan Kerja, Kompetensi, dan Kompensasi terhadap Kepuasan Kerja dan Kinerja Pegawai di Lingkungan Kantor Dinas Pekerjaan Umum Provinsi Bali menyatakan bahwa Motivasi dan lingkungan kerja tidak berpengaruh signifikan terhadap kepuasan kerja Kompetensi dan kompensasi berpengaruh signifikan terhadap kepuasan kerja. Hasil penelitian lainnya senada dengan penelitian yang dilakukan I Putu Candra Giritama I Wayan Suana (2013) dengan judul penelitian Pengaruh Pelatihan Kerja dan Kompensasi terhadap Kepuasan Kerja serta Dampaknya terhadap Prestasi Kerja Karyawan Koperasi Serba Usaha Kuta Mimba di Kuta-Badung menyatakan bahwa Pelatihan kerja dan kompensasi berpengaruh signifikan terhadapkepuasan kerja karyawan. Pelatihan kerja, kompensasi dan kepuasan kerja berkontribusi secara positif dan signifikan terhadap prestasi kerja karyawan.

\section{Kontribusi Motivasi Kerja (X2) Terhadap Kepuasan Kerja Pegawai di Dinas Pendidikan Dan Kebudayaan Kabupaten Agam (Y)}

Hasil penelitian menunjukkan bahwa variabel motivasi kerja berkontribusi positif terhadap kepuasan kerja karyawan. Hal ini dibuktikan dengan hasil statistik uji regresi diperoleh nilai sebesar $(\beta), 495(* * p<0.05 ; p=0,001)$. Kontribusi kontribusi motivasi kerja terhadap kepuasan kerja pegawai sebesar (R2) 0,191; maka penelitian ini berhasil membuktikan hipotesi kedua. Hotgets dan Luthans dalam Susanto (2006: 144) menyatakan bahwa motivasi merupakan proses psikologis melalui keinginan yang belum terpuaskan, yang diarahkan dan didorong ke pencapaian tujuan atau insentif. Proses dasar motivasi dimulai dengan adanya suatu kebutuhan (needs). Kebutuhan tercipta ketika ada ketidakseimbangan secara fisiologis dan secara psikologis. Kemudian kebutuhan tersebut didorong dan diarahkan (drives) untuk mengurangi kekurangan akan kebutuhan. Dorongan fisiologis dan psikologis merupakan kegiatan yang berorioentasi dan menyediakan tenaga untuk mendapatkan insentif. Akhir dari proses motivasi adalah insentif yang didefinisikan sebagai segala sesuatu yang akan mengurangi kekurangan akan kebutuhan dan mengurangi dorogan. Insentif akan memulihkan keseimbangan fisiologis dan psikologis dan mengurangi atau menghentikan dorongan.

Setiap karyawan harus memiliki motivasi kerja yang tinggi sehingga dapat meningkatkan kepuasan kerja dan produktifitas yang baik bagi perusahaan, apabila setiap karyawan PT Aseli Dagadu Djokdja memiliki motivasi kerja yang tinggi tentunya juga akan berimbas pada loyalitas terhadap perusahaan, disiplin kerja, dan produktifitasnya hal ini juga tentunya akan sangat berimbas pada kepuasan kerja karyawan. Apabila karyawan memiliki keinginan yang kuat untuk terus berprestasi, memiliki hubungan yang harmonis dengan karyawan yang lain dan memiliki keinginan yang kuat untuk mendapatkan promosi jabatan dari atasan maka motivasi kerja yang dimiliki karyawan sangatlah baik dan sangat berpengaruh terhadap kepuasan kerja yang tumbuh dari dalam diri karyawan saat berkeja pada perusahaan PT Aseli Dagadu Djokdja. Hal ini mendukung penelitian yang di lakukan oleh Ayu Brahmasari dan Suprayetno (2009) yang berjudul Pengaruh Motivasi Kerja, Kepemimpinan dan E-ISSN: 2657-0300 Lembaga Penelitian dan Penerbitan Hasil Penelitian Ensiklopedia $\quad 25$ 
Budaya Organisasi Terhadap Kepuasan Kerja Karyawan serta Dampaknya pada Kinerja Perusahaan (Studi kasus pada PT. Pei Hai International Wiratama Indonesia), memiliki kesimpulan bahwa motivasi kerja berkontribusi positif dan signifikan terhadap kepuasan kerja karyawan.

Kontribusi Kompensasi (X1) dan Motivasi Kerja (X2) Terhadap Terhadap Kepuasan Kerja Pegawai di Dinas Pendidikan Dan Kebudayaan Kabupaten Agam (Y)

Hasil penelitian menunjukkan bahwa variabel kompensasi dan motivasi kerja secara bersama-sama berkontribusi positif terhadap kepuasan kerja karyawan. Hal ini dibuktikan dengan hasil statistik uji regresi diperoleh nilai kompensasi $\beta, 444$ $\left({ }^{*} p<0.05 ; p=0,000\right)$ dan motivasi kerja $\beta, 495(* p<0.05 ; p=0,000)$ berkontribusi positif terhadap kepuasan kerja karyawan. Kontribusi kompensasi dan motivasi kerja terhadap kepuasan kerja sebesar (R2) 0,257, maka hipotesis ketiga diterima.

Suwanto dan Donni (2011:263) Kepuasan kerja adalah cara individu merasakan pekerjaan yang dihasilkan dari sikap invidu tersebut terhadap berbagai aspek yang dihasilkan dari sikap individu tersebut terhadap berbagai aspek yang terkandung dalam pekerjaan. Kepuasan kerja sendiri juga dapat di pengaruhi oleh kompensasi, menurut Notoadmodjo (1998: 143) kompensasi adalah segala sesuatu yang diterima oleh karyawan sebagai balas jasa untuk kerja mereka. Kompensasai tentunya dapat memengaruhi kepuasan kerja karyawan hal ini mendukung penelitian sebelumnya yang dilakukan dilakukan oleh Putri (2014) dengan judul Pengaruh Gaya Kepemimpinan, Budaya Organisasi, dan Kompensasi Finansial Terhadap Kepuasan Kerja Karyawan Pada PT. Dunia Garmen Internasional di Denpasar, memiliki kesimpulan bahwa Hasil pembahasan tersebut menghasilkan data bahwa kompensasi memiliki pengaruh signifikan secara simultan terhadap kepuasan kerja pegawai pada PT. Dunia Garmen Internasional Denpasar dengan kontribusi sebesar 19,8 persen, dapat disimpulkan bahwa variabel kompensasi yang paling memengaruhi kepuasan kerja karyawan.

Tidak hanya kompensasi yang dapat memengaruhi kepuasan kerja karyawan akan tetapi motivasi kerja juga sangat memengaruhi kepuasan kerja karyawan. Motivasi kerja memiliki peran yang cukup besar dalam menumbuhkan kepuasan kerja karyawan, apabila setiap karyawan PT Aseli Dagadu Djokdja memiliki motivasi kerja yang baik kemudian didukung dengan kompensasi yang layak dari perusahaan baik kompensasi materiil dan non materi maka kepuasan kerja karyawan PT Aseli Dagadu Djokdja akan sangat tinggi. Hotgets dan Luthans dalam Susanto (2006: 144) menyatakan bahwa motivasi merupakan proses psikologis melalui keinginan yang belum terpuaskan, yang diarahkan dan didorong ke pencapaian tujuan atau insentif. Hal ini juga mendukung penelitian sebelumnya yang dilakukan oleh Kristianto (2013) dengan judul Analisis Pengaruh Motivasi Kerja, Pengembangan Karir dan Kepemimpinan terhadap Kepuasan Kerja di PT. Kapasari di Surabaya dari penelitian di atas dapat disimpulkan bahwa motivasi kerja memiliki pengaruh signifikan pada kepuasan kerja. Hal ini dibuktikan dengan kebijakan dan tunjangan yang diberikan oleh Dinas pendidikan Dan Kebudayaan Kabupaten Agam yang mendorong motivasi pegawai dalam melakukan pekerjaan sehingga kinerja pegawai di Dinas Pendidikan Dan Kebudayaan Kabupaten Agam dapat dilaksanakan semaksimal mungkin serta pegawai merasa pekerjaan yang dilakukan tidak membuat jenuh. 


\section{Penutup}

Berdasarkan hasil penelitian dan pembahasan, maka dapat ditarik beberapa kesimpulan sebagai berikut: Kompensasi berkontribusi positif terhadap kepuasan kerja pegawai. Artinya bahwa semakin baik kompensasi yang diberikan maka semakin baik pula kepuasan kerja yang dihasilkan. Motivasi kerja berkontribusi positif terhadap kepuasan kerja karyawan. Artinya bahwa semakin baik motivasi kerja yang diberikan maka semakin baik pula kepuasan kerja yang dihasilkan. Kompensasi dan motivasi kerja mempunyai kontribusi positif terhadap kepuasan kerja karyawan. Artinya, apabila di Dinas Pendidikan Dan Kebudayaan Kabupaten Agam dapat memberikan kompensasi yang baik serta didukung dengan motivasi kerja yang baik pula maka akan menghasilkan kepuasan kerja yang baik bagi karyawan.

\section{Daftar Pustaka}

Donni Juni Priansa. 2016. Perencanaan dan Pengembbangan SDM. Bandung: CV Alfabeta

Fathoni, Abdurrahmat. 2006. Manajemen Sumber Daya Manusia. Jakarta: PT Rineka Cipta.

Gibson, James L, et al. 2010. Organizations : Behaviour, Structure, Processess. $14^{\text {th }}$ ed. Boston. Mc-Graw-Hill

Handoko, Hani. 2012. Manajemen Personalia dan Sumber Daya Manusia.Yogyakarta : BFE-Yogyakarta.

Hariandja, Marihot Tua Efendi. 2007. Manajemen Sumber Daya Manusia : Pengadaan, Pengembangan, Pengkompensasian, dan Peningkatan Produktivitas Pegawai. Jakarta : Grasindo

Ivancevich, John M. and Lee Soo Hoon. 2002. Human Resource Management in Asia. Boston: Mc-Graw-Hill

Kaswan. 2013. Pelatihan dan Pengembangan untuk Meningkatkan Kinerja SDM. Bandung: CV Alfabeta

Kreitner dan Kinichi. 2005. Organization Behavior. Boston: Mc-Graw-Hill

Malayu SP Hasibuan. 2005. Manajemen Sumber Daya Manusia. Jakarta : PT Bumi Aksara.

Mathis, Robert L., John H. Jackson. 2001. Manajemen Sumber Daya Manusia. Jakarta: Salemba Empat

Moh.Nazir. 2005. Metode Penelitian. Bogor : Penerbit Ghalia Indonesia

Rivai, Veithzal. 2009. Manajemen Sumber Daya Manusia Untuk Perusahaan Dari Teori ke Praktik. Jakarta: Raja Grafindo Persada

Spector, P.E., 1997. Job Satisfaction: Application, assessment, causes, and consequences (Vol. 3). Sage publications.

Stone, Raymond J.. 2011. Human Resource Management. Australia: Australian Human Resurce Institute

Siagian, Sondang (2008). Manajemen Sumber Daya Manusia. Jakarta: Bumi Aksara.

Suparno Eko Widodo. 2015. Manajemen Pengembangan Sumber Daya Manusia. Yogyakarta:Pustaka Pelajar

Suwatno dan Donni.2011. Manajemen SDM dalam Organisasi Publik dan Bisnis. Bandung: CV Alfabeta

Cong, N.N. and Van, D.N., 2013. Effects of motivation and job satisfaction on employees' performance at Petrovietnam Nghe An Construction Joints Stock Corporation (PVNC). International Journal of Business and Social Science, 4(6). 
Lodjo, F.S., 2013. Pengaruh Pelatihan, Pemberdayaan dan Efikasi Diri Terhadap Kepuasan Kerja. Jurnal Riset Ekonomi, Manajemen, Bisnis dan Akuntansi, 1(3).

Mulia, R. A. (2019). Influence Of Public Policy, Participation Of Community And Education Level To Public Welfare In Padang Pariaman District. Jurnal ELRIYASAH, 10(1), 37-56.

Mulia, R. A., \& Fitri, A. (2019). Pengaruh Karakteristik Kepemimpinan Terhadap Motivasi Kerja Karyawan Di Pt. Mega Medica Pharmaceuticals.

Mujib, A., 2012. Motivasi Berprestasi sebagai Mediator Kepuasan Kerja.Jurnal Psikologi, 39(2), pp.143-155.

Ruthankoon, R. and Olu Ogunlana, S., 2003. Testing Herzberg's two-factor theory in the Thai construction industry.Engineering, Construction and Architectural Management, 10(5), pp.333-341.

Schmidt, Stephen W. 2007. The Relationship Between Satisfaction with Workplace Training and Overall Job Satisfaction. Human Resource Development Quarterly.Vol 18 No. 4.Wiley Periodicals Inc. 